\title{
Globalization AND THE PRICE DeCline OF ILLICIT DRUGS
}

\author{
CLÁUdia COSTA STORTI \\ PAUl De GRAUWE
}

CESIFO WORKING PAPER NO. 1990

CATEgory 7: TRAde Policy

MAY 2007

An electronic version of the paper may be downloaded

- from the SSRN website:

- from the RePEc website:

www.SSRN.com

- from the CESifo website: 


\title{
Globalization AND THe PRICE DeCline OF ILLICIT DRUGS
}

\begin{abstract}
Retail prices of major drugs like cocaine and heroin have declined dramatically during the last two decades. This price decline has tended to offset the effects of drug policies aimed at reducing drug use in major industrial countries. The main finding of this paper is that the decline in the retail prices of drugs is related to the strong decline in the intermediation margin (the difference between the retail and producer prices) in the drug business. We develop the hypothesis, and give some evidence, that globalization has been an important factor behind the decline of the intermediation margin. We conclude with some thoughts about the effects of globalization on the effectiveness of drug policies and argue that globalization may have increased the relative effectiveness of policies aiming at reducing the demand of drugs.
\end{abstract}

JEL Code: F10, K42.

\author{
Cláudia Costa Storti \\ Banco de Portugal \\ Ave. Almirante Reis 72 \\ 1150 Lisboa \\ Portugal \\ cstorti@bportugal.pt
}

\author{
Paul De Grauwe \\ Catholic University Leuven \\ Center for Economic Studies \\ Naamsestraat 69 \\ 3000 Leuven \\ Belgium \\ paul.degrauwe@econ.kuleuven.be
}

April 2007 


\section{Introduction}

In the last decades a remarkable empirical phenomenon has occurred in the drug markets. The retail prices of well-known hard drugs have declined spectacularly. We show the evidence in figures 1 and 2. These present the price evolution (at the retail level) of cocaine and heroin in the US and in Europe. We observe that these prices have dropped from $50 \%$ to $80 \%$ since 1990 .

There is evidence that these retail price declines started before 1990, and that it also applies to other drugs than cocaine and heroin ${ }^{1}$. We show some evidence for the US where these data have been collected for a longer time (since 1981). In this paper we will concentrate on the period since 1990 because that period has the most consistent set of data.

How can such a spectacular price decline be explained? This is the question addressed in this paper. We start by presenting a very simple model of demand and supply of drugs, so as to identify the potential factors that can explain this price decline. We then formulate our hypothesis, which is that the forces of globalization are the main reason why drug prices have declined. Globalization has fundamentally affected the drug industry in different ways. We will analyze these different mechanisms. In a further section we present some empirical evidence that confirm our main hypothesis. We conclude with a section on the policy implications of our findings.

\footnotetext{
${ }^{1}$ For cannabis, most widely used drug we could not find long enough time series of prices.
} 
Figure 1:

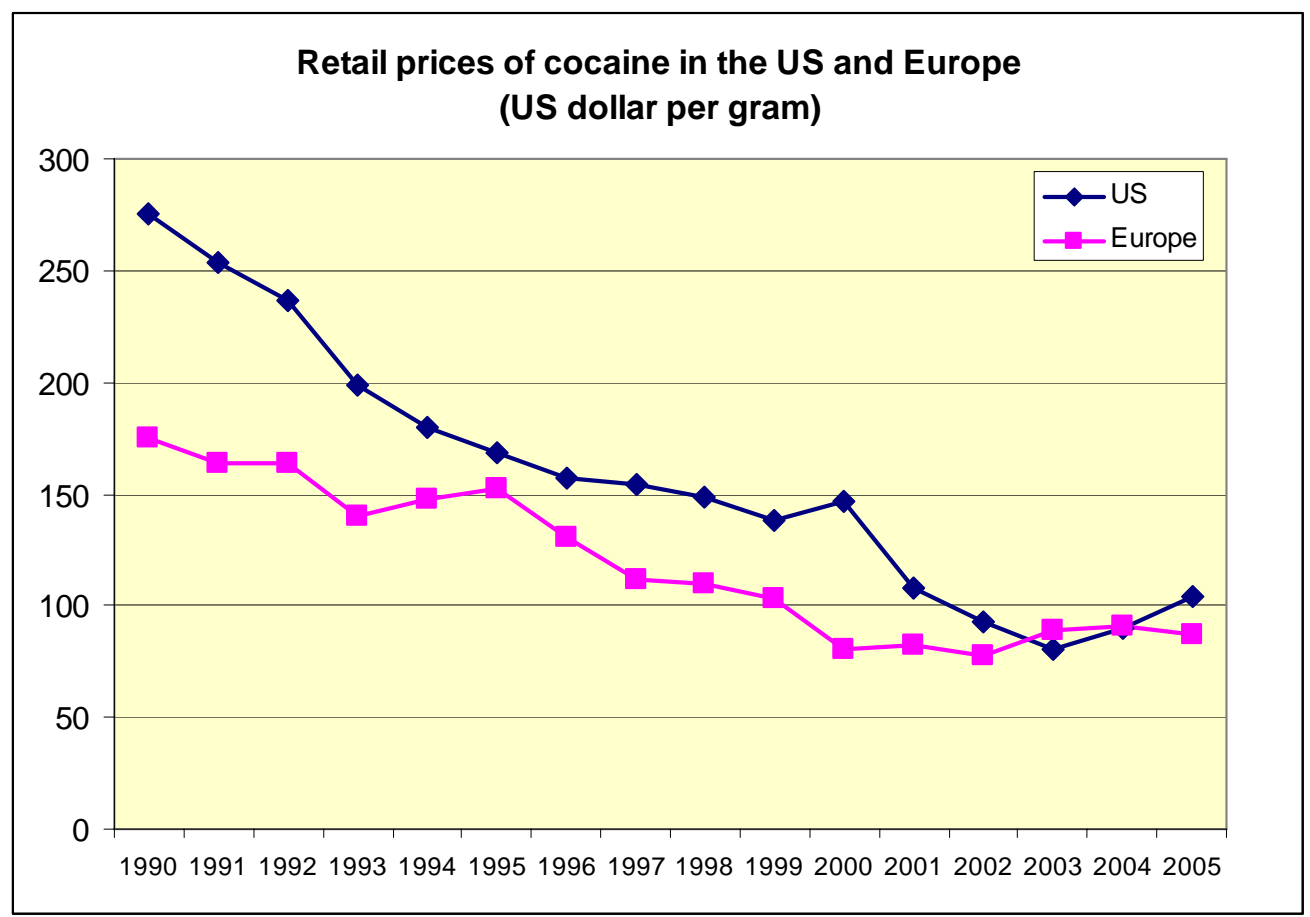

Source: United Nations, World Drug Report 2006, Office on Drugs and Crime, New York

\section{Figure 2}

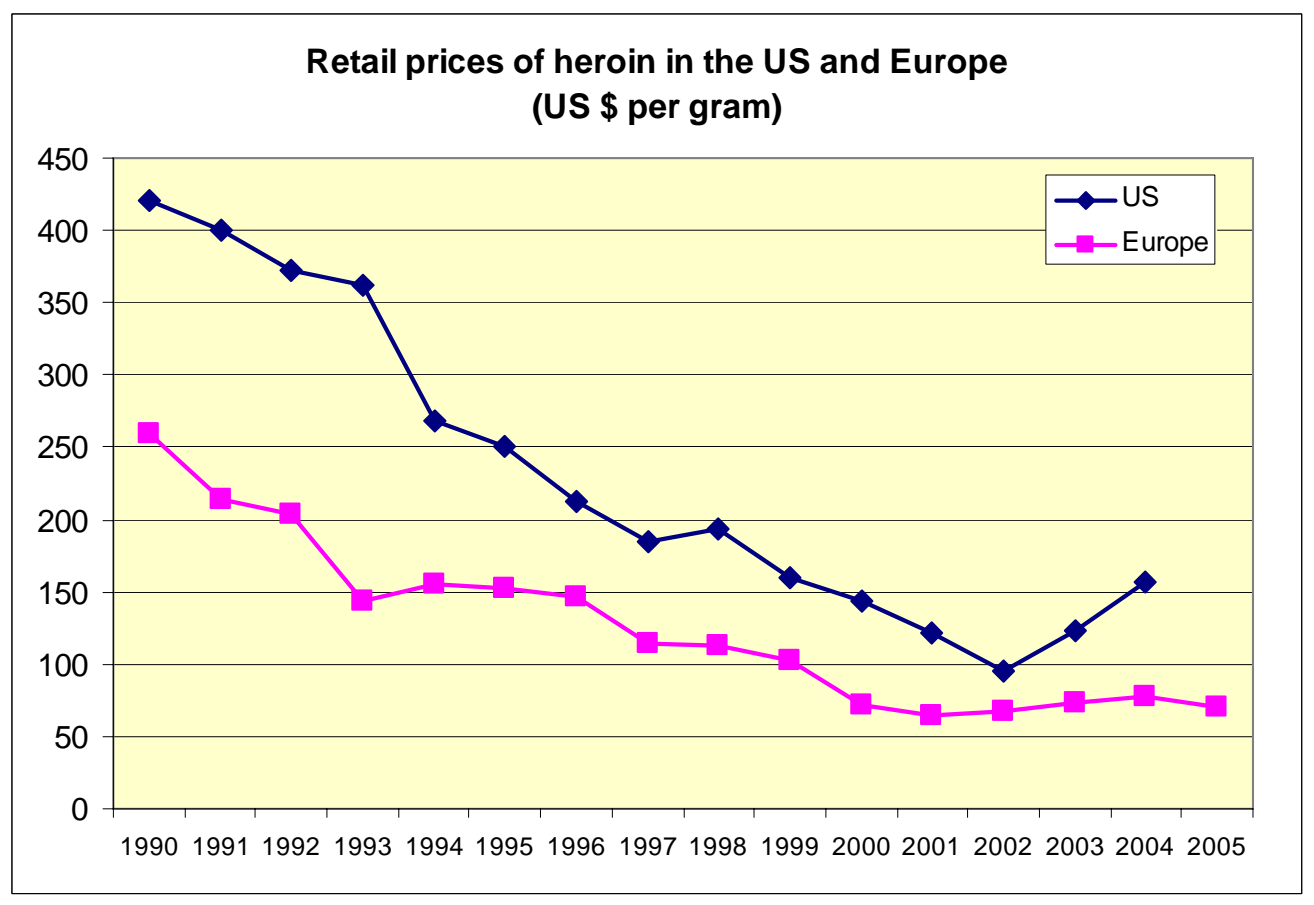

Source: United Nations, World Drug Report 2006, Office on Drugs and Crime, New York 


\section{Demand and supply of drugs}

In this section we present a simple model of demand and supply in the drugs market ${ }^{2}$. The purpose of this classroom model is to identify the factors that can be invoked to explain the large decline in the retail price of drugs. We will call the drug in this very simple model “cocaine”.

Figure 3 presents demand and supply for cocaine at the retail level. We focus first on the supply curve. This embodies an important characteristic of the drug market i.e. that by far the largest part of the retail cost consists of the intermediation margin. The cost of producing coca leafs is a tiny fraction of the total retail cost. It is variously estimated to be less than $1 \%$ of the retail price (see Caulkins, et al.(2005)).

Thus the intermediation margin constitutes by far the largest part of the retail price. Figure 3 does not give full credit to this feature, but only suggests this difference by locating the producers' supply curve way below the retail supply curve.

Figure 3: Demand and supply of cocaine

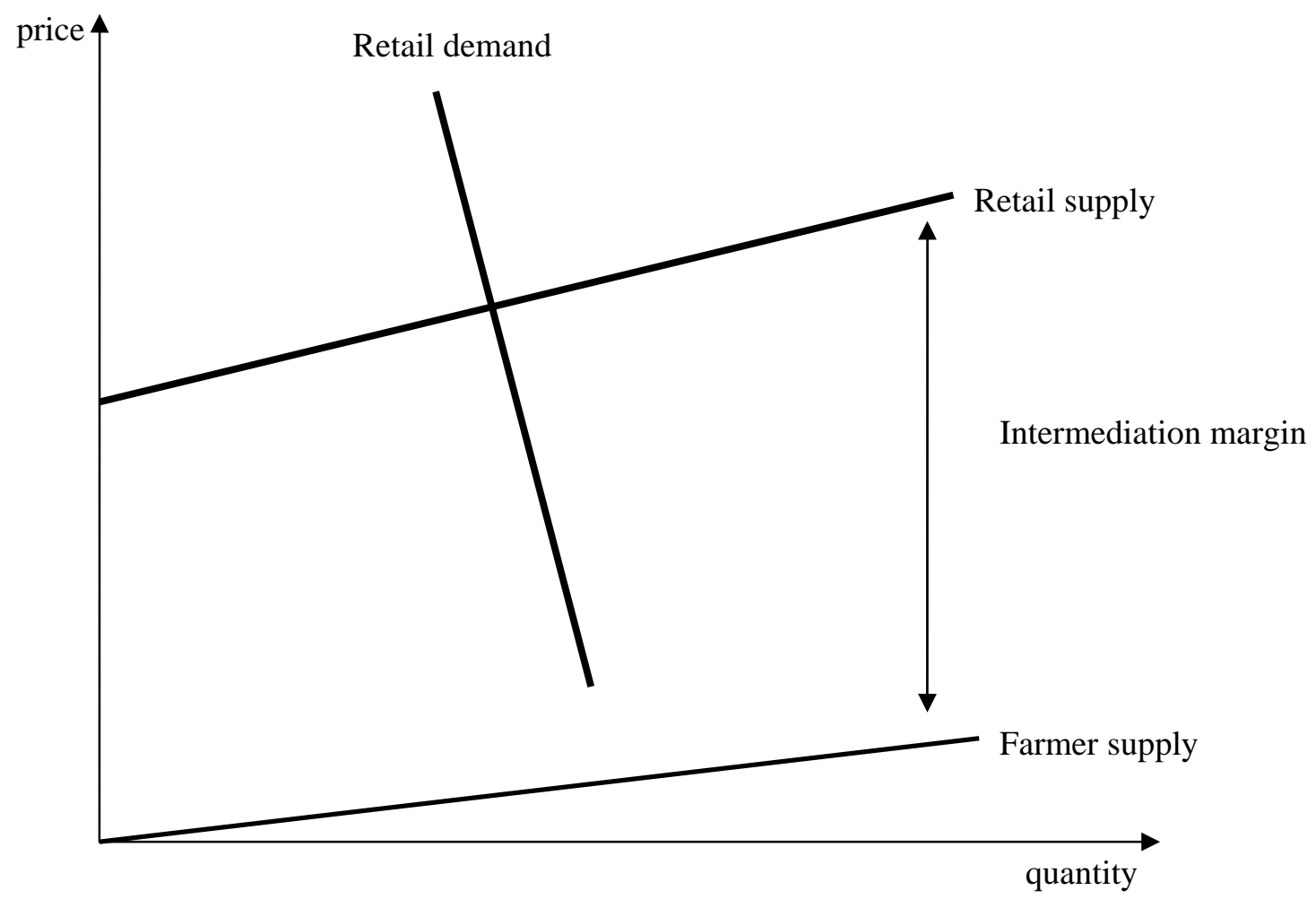

\footnotetext{
2 See also Becker at al. (2005)
} 
The relation between the retail and producer (farmer) supply curves represented in figure 1 can be analyzed as follows. We start by writing the producer supply curve as a simple linear function with unit price elasticity ${ }^{3}$ :

$$
P_{f}=\alpha X_{S}
$$

where $P_{f}$ is the producer price and $X_{S}$ is the supply of cocaine. We then write the retail price as follows:

$$
P=P_{f}+M \quad P=P_{f}+M
$$

Where $P$ is the retail price and $\mathrm{M}$ is the intermediation margin. We specify the latter as:

$$
M=\bar{M}+\beta X_{S}
$$

where $\bar{M}$ is the fixed component of the intermediation margin and $\beta X_{S}$ is the variable component of the intermediation margin.

What are the factors affecting the intermediation margin? Let us list the most important ones.

- The risk premium. Since the distribution and sale of drugs is illegal in most countries and since the penalty on these activities is stiff, those who engage in these activities take a risk (confiscation, prison, violence.). They will only engage in these activities if they obtain a risk premium ${ }^{4}$. Given the nature of the risk, this risk premium is likely to be large. This factor is likely to make the fixed component of the intermediation margin large.

- Efficiency of intermediation. The more efficient the intermediation process (stock management, transportation and distribution) the lower the costs. There is a potential spillover here with the risk premium: a more efficient intermediation reduces the number of intermediaries involved and thus reduces the risk premium. Substituting (2) and (3) into (1) yields:

$$
P=(\alpha+\beta) X_{S}+\bar{M}
$$

\footnotetext{
${ }^{3}$ This assumption of unit elasticity is made for the sake of convenience. It does not affect the nature of the analysis.

${ }^{4}$ See Kuziemko and Levitt(2003).
} 
which describes the retail supply curve. Note that the slope of the retail supply curve (given by $\alpha+\beta$ ) will generally be different from the slope of the producer supply curve (given by $\alpha$ ).

This simple model allows us to write the elasticity of the retail supply curve as

$$
\frac{P}{P-\bar{M}}
$$

Equation (5) implies that if the fixed intermediation margin is high, the retail price elasticity can become very large. Equation (5) can be rewritten as

$$
\frac{P}{P_{f}+\beta X_{S}}
$$

One can simplify (6) further by assuming that $\beta=0$, i.e. the intermediation margin has only a fixed component ${ }^{5}$. In that case we obtain the following expression for the price elasticity of the retail supply:

$$
\frac{P}{P_{f}}
$$

i. e. the price elasticity of the retail supply curve is equal to the ratio of the retail price to the producer price (given that we have assumed a unit price elasticity of the producer supply curve) ${ }^{6}$. The larger is this ratio, the higher is the price elasticity of the retail supply curve for any given elasticity of the producer supply curve. To illustrate the nature of equation (5), suppose that the retail price is 100 times higher than the producer price (which is the order of magnitude observed in reality ${ }^{7}$ ), then the price elasticity of the retail supply curve will be equal to 100 (given that the producer supply equation has unit elasticity). Thus in the drug market the price elasticity of the retail supply is likely to be several orders of magnitude higher than the price elasticity of the producers' supply.

\footnotetext{
${ }^{5}$ This assumption makes sense as we really do not know how the supply affects the risk premium, i.e. we do not know whether $\beta$ is positive or negative.

${ }^{6}$ As mentioned earlier this assumption is made for the sake of simplicity. Making a more general assumption will not alter the main result, i.e. that the price elasticity of the retail supply is a multiple of the price elasticity of the producers' supply.

${ }^{7}$ See the evidence provided by Caulkins, et al. (2005) cited earlier.
} 
The retail demand curve is represented by a relatively steep curve, reflecting the empirical evidence that the price elasticity of demand is relatively small. There is evidence, however, that the price elasticity is not zero, i.e. that demand does respond to price (see Abt Associates(2000), Saffer and Chaloupka(1995), Dave(2004), $\operatorname{Grossman}(2004))^{8}$.

The previous theoretical analysis allows us to identify the likely causes of the large observed decline in retail prices. Such a decline can be due to three different causes

- An increased supply by producers

- A reduced demand by consumers

- A decline in the intermediation margin

From Figure (1) it can be seen that the first two factors are unlikely to be of great importance. We observe from Figure (1), first, that even if the producers' supply curve were to shift downwards so as to coincide with the x-axis (coca leaves would then have become free goods) the effect of this shift on the retail supply curve would be minimal, leaving the retail price of cocaine pretty much unchanged.

Second, the massive price declines are unlikely to have been the result of declines in demand. These would have had to be massive also. This follows from the fact that the retail supply curve is relatively elastic. The latter follows from the existence of a large intermediation margin. Thus, in order to produce a retail price decline of $80 \%$, a demand reduction should have been truly massive. We will analyze whether there is any empirical evidence for such a large decline of demand.

Given that shifts in the supply and demand curves are unlikely candidates to explain the large observed price declines, the core of the explanation is likely to be found in large reductions in the intermediation margin. In other words, the large price declines

\footnotetext{
${ }^{8}$ Abt Associates(2000) find a price elasticitiy of the demand (by moderate users) for heroin of -0.17 and for cocaine of -0.26 . Saffer and Chaloupka(1995) find higher price elasticities, i.e. between -1.10 to -0.72 for cocaine and between -1.80 and -1.60 for heroin in the US. Dave(2004) computes the probability of an admission in hospital emergency departments in the US and finds that the elasticity of this probability is -0.27 for cocaine and -0.15 for heroin. Grossman(2004) computes similar elasticites and finds that these are between -1.7 and -0.1 for cocaine and between -0.6 and +0.1 for heroin in the US. The price elasticities estimated by Dave and Grossman are not conventional price elastiticies. They do suggest, though that drug demand is sensitive to price. On the whole the evidence suggests that the demand for heroin and cocaine responds moderately to prices. It should be mentioned though that some authors find no evidence of prices sensitivity of the demand for cocaine and heroin (e.g. Ramful and Zhao (2003) for Australia).
} 
are likely to be due to a combination of large declines in the risk premium and large increases in the efficiency of the intermediation.

In the next section we provide some empirical evidence on the evolution of the three factors identified in this section.

\section{Empirical analysis}

The way we precede in this section is as follows. We present statistical information on the three fundamental determinants of the retail price of drugs, i.e, on the worldwide production and consumption of drugs and on the intermediation margin.

\subsection{Worldwide supply of drugs.}

We supply data on the three most important drugs, cocaine, heroin and cannabis. Figure 4 presents data on the global production of cocaine since 1990. This production is concentrated in three countries Bolivia, Colombia and Peru. Fig 4 shows that the global production of cocaine has stagnated since 1990. The stagnating global production observed in figure 4 is the outcome of two opposing forces. First, the global coca leafs cultivation area has declined from approximately 210,000 ha in 1990 to 160,000 ha in 2005 . Second, this decline which was the result of eradication efforts was compensated by an increase of the average yield per ha.

The worldwide production of opium (used to produce heroin) is shown in figure 5 . The production of opium is concentrated in mainly three countries, Afghanistan, Myanmar and Laos. We observe a similar trend as in the cocaine market, i.e. a stagnating worldwide production. As in the case of cocaine, this trend conceals two opposing tendencies. On the one hand, there is a significant decline in the worldwide area under cultivation from more that 250,000 ha in 1990 to about 150,000 in 2005. On the other hand, the international efforts at eradicating the cultivation of poppy has been countered by an increase in the yield per ha. 
Figure 4: Global production of cocaine (metric tons) , 1990-2005

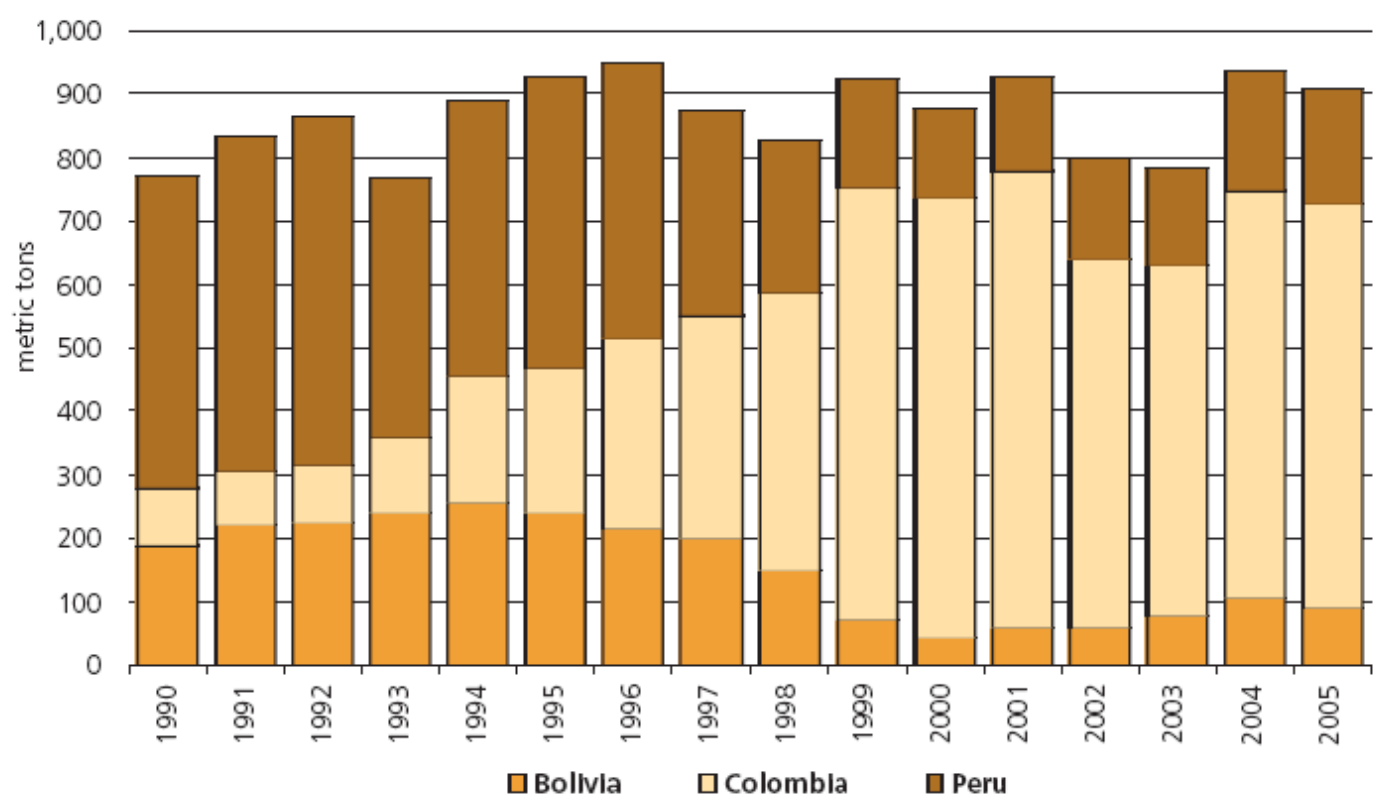

Source: United Nations, World Drug Report 2006, Office on Drugs and Crime, New York

Figure 5: Global opium production (metric tons), 1990-2005

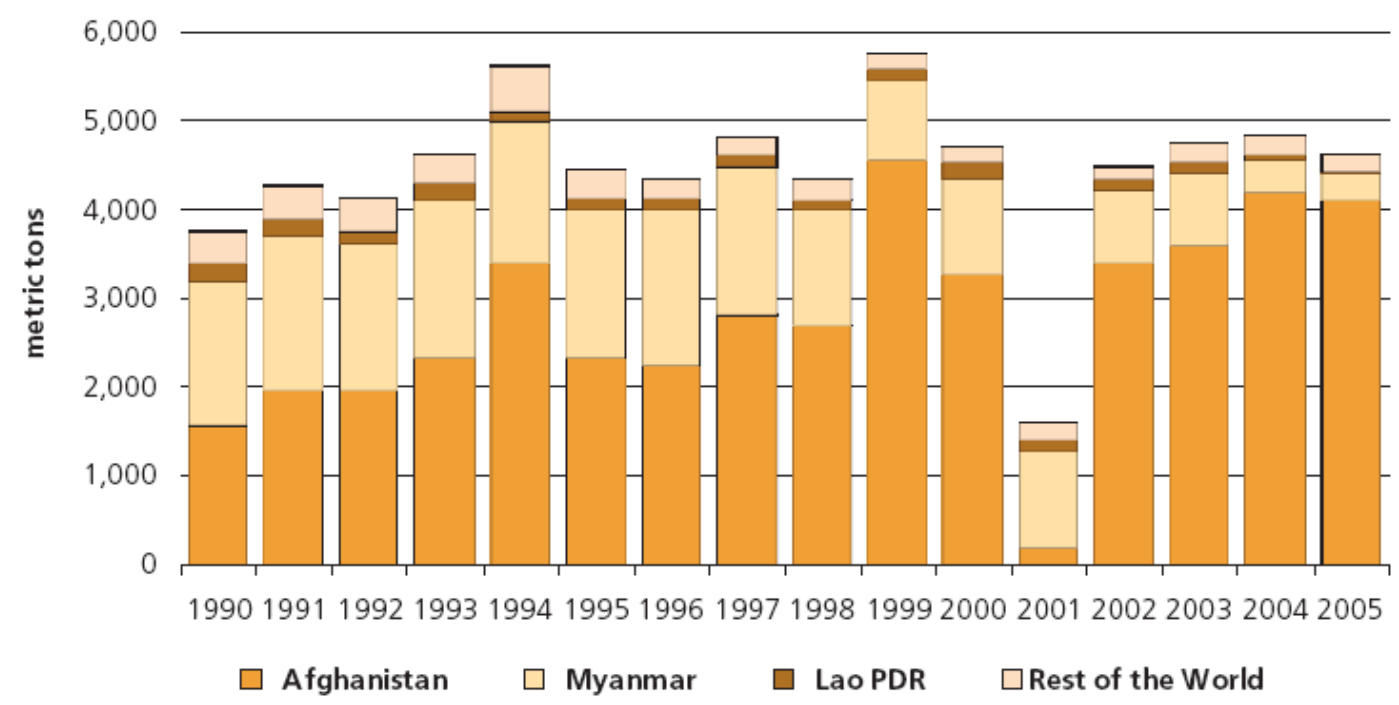

Source: United Nations, World Drug Report 2006, Office on Drugs and Crime, New York

In this section we also show some evidence on other drugs than cocaine and heroin, in particular on cannabis. In contrast to cocaine and opium the production of cannabis is not regionally concentrated. Cannabis, either in the form of herb or resin, can be 
produced in virtually every country. According to the UN World Drug Report (2006) cannabis herb is cultivated in some 176 countries (p. 103). This makes the estimation of the worldwide production very difficult. Nevertheless some rough indication of the trends in the worldwide supply can be obtained. Figure 6 shows an estimate of the evolution of the worldwide production of cannabis herb since the end of the 1980s. We observe that after a decline in the worldwide production in the 1990s, production has picked up again since the late 1990s. As a result in 2004/05 the production stood approximately $36 \%$ above the level of the late 1980s. Thus, in contrast to the cocaine and heroin markets, we observe an increase in the worldwide production of cannabis. This increase, however, remains relatively limited, amounting to less than $2 \%$ per year.

To conclude this discussion of the trends in production it is useful to analyze the price evolution at the producer level ("farm-gate prices"). The data that can be found are not as comprehensive as the production data (i.e., we could not find reliable producer prices of cannabis over an extended period). Also, the price data typically cover only part of the different producing countries.

Figure 6 : Estimates of global cannabis herb production

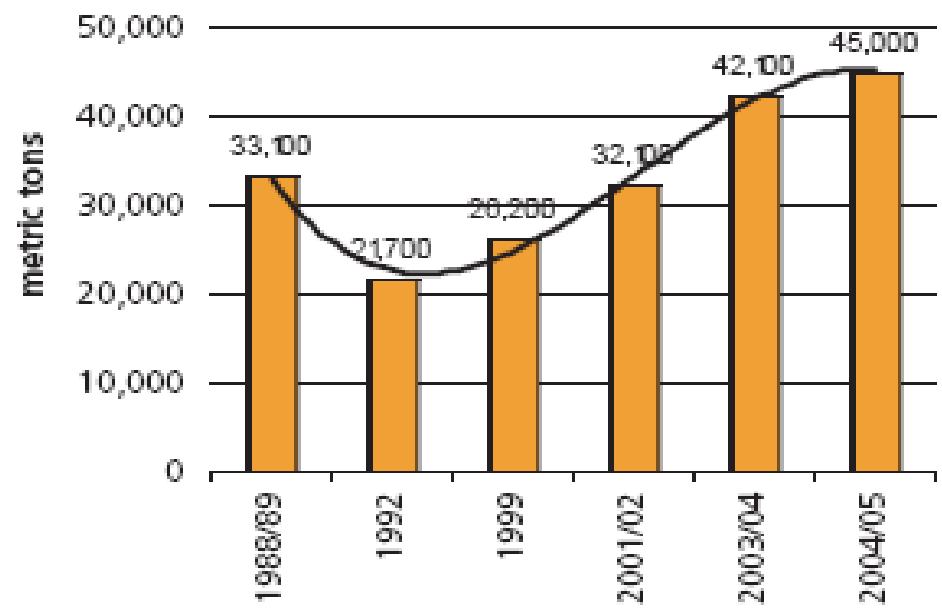

Source: United Nations, World Drug Report 2006, Office on Drugs and Crime, New York 
In figure 7 we show the producer prices of coca leafs since 1990. Although yearly fluctuations in the three different countries can be quite different, an increasing trend in the producer prices can be detected from 1999 to 2005.

The price data of opium are even scarcer. Figure 8 shows the prices of dry opium in Afghanistan from 1997 to early 2006. We observe a large price peak that is related to the war in Afghanistan. From 2003 on, prices decline forcefully. Nevertheless, over the whole period from 1997 to 2005 we observe an increase (almost doubling) of the price of dry opium. Thus, in both the coca leaf market and in the opium market the evidence suggests that prices have been on an upward trend.

\section{Figure 7}

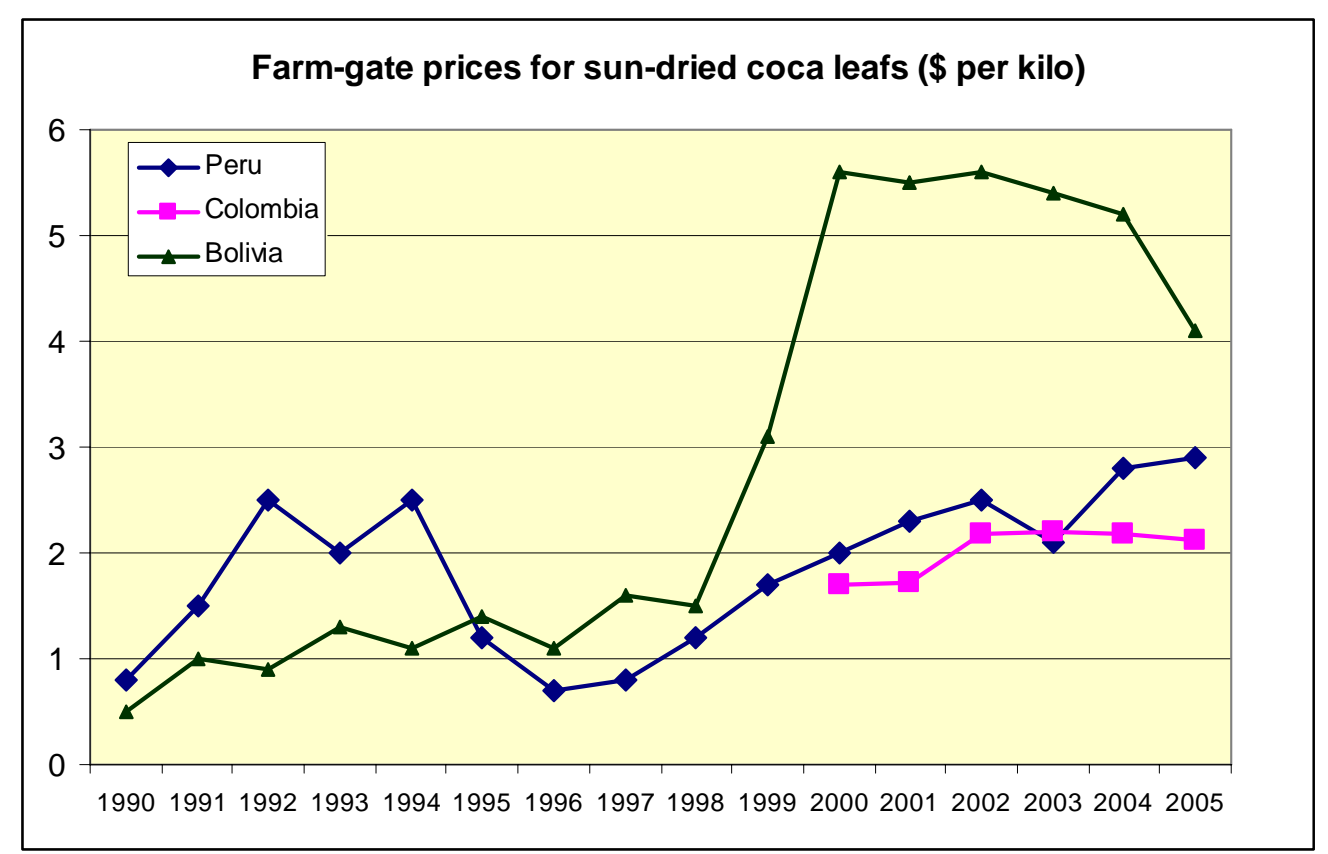

Source: United Nations, World Drug Report 2006, Office on Drugs and Crime, New York Note: The prices of Colombia relate to cocaine paste prices 
Figure 8 : Prices of dry opium in Afghanistan (\$ per kilo)

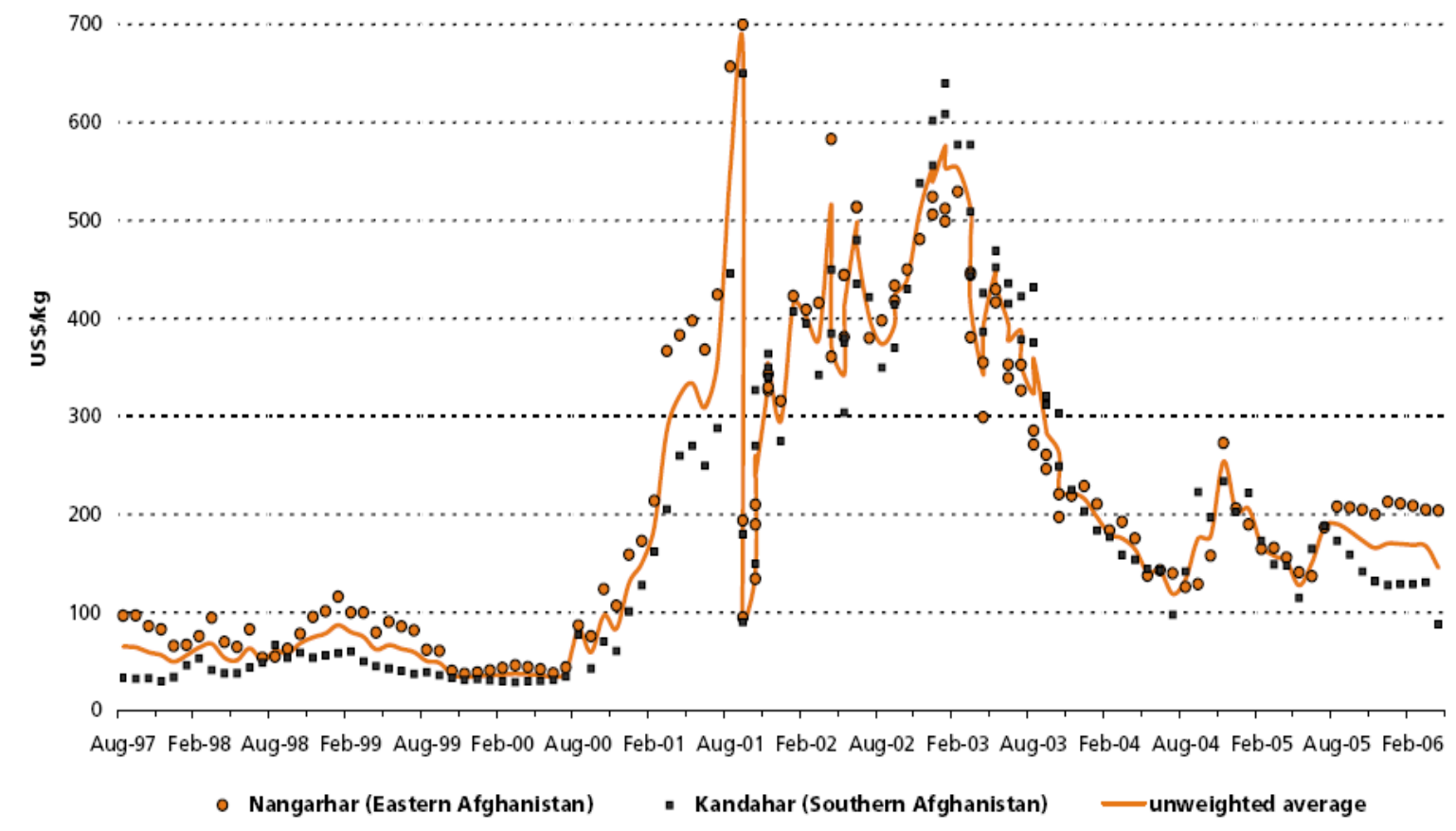

Source: United Nations, World Drug Report 2006, Office on Drugs and Crime, New York

\subsection{Worldwide consumption of drugs}

In the following three figures 9-11 we present the evolution of the use of heroin, cocaine and cannabis in Europe and in the US. The general picture we obtain is that the drug use in Europe and the US has been on an upward trend since the early 1990s. In Europe the use of heroin and cocaine has increased faster than their worldwide use, while in the US the use of these same drugs has increased less fast than in the rest of the world. As far as cannabis is concerned, both the European and the US consumption levels have increased faster than world consumption.

Thus the picture we obtain from this analysis of consumption data and from the previous section's analysis of the production side is the following. The increased demand for drugs (at the retail level) has put upward pressure on the producer prices. Production, however, has not increased much (in the cases of coca and opium) probably because of the efforts of eradication have reduced the cultivation areas. However, higher yields per ha have made it possible for producers to continue to supply approximately the same amount of drugs in the world markets. 
From this analysis it appears that the sharp decline in the retail prices cannot easily be explained by the trends in world production and consumption. Indeed, the paradox we noted in the beginning is even stronger than we thought. Retail prices have declined dramatically despite an increase in the producer prices during the same period. This leads us into an analysis of the intermediation margin.

\section{Figure 9: Index of heroin use from 1992 to 2004}

Europe

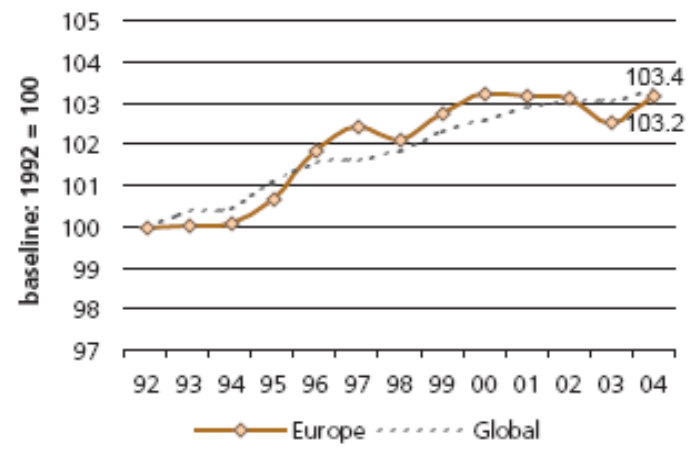

Figure 10: Index of cocaine use from 1992 to 2004
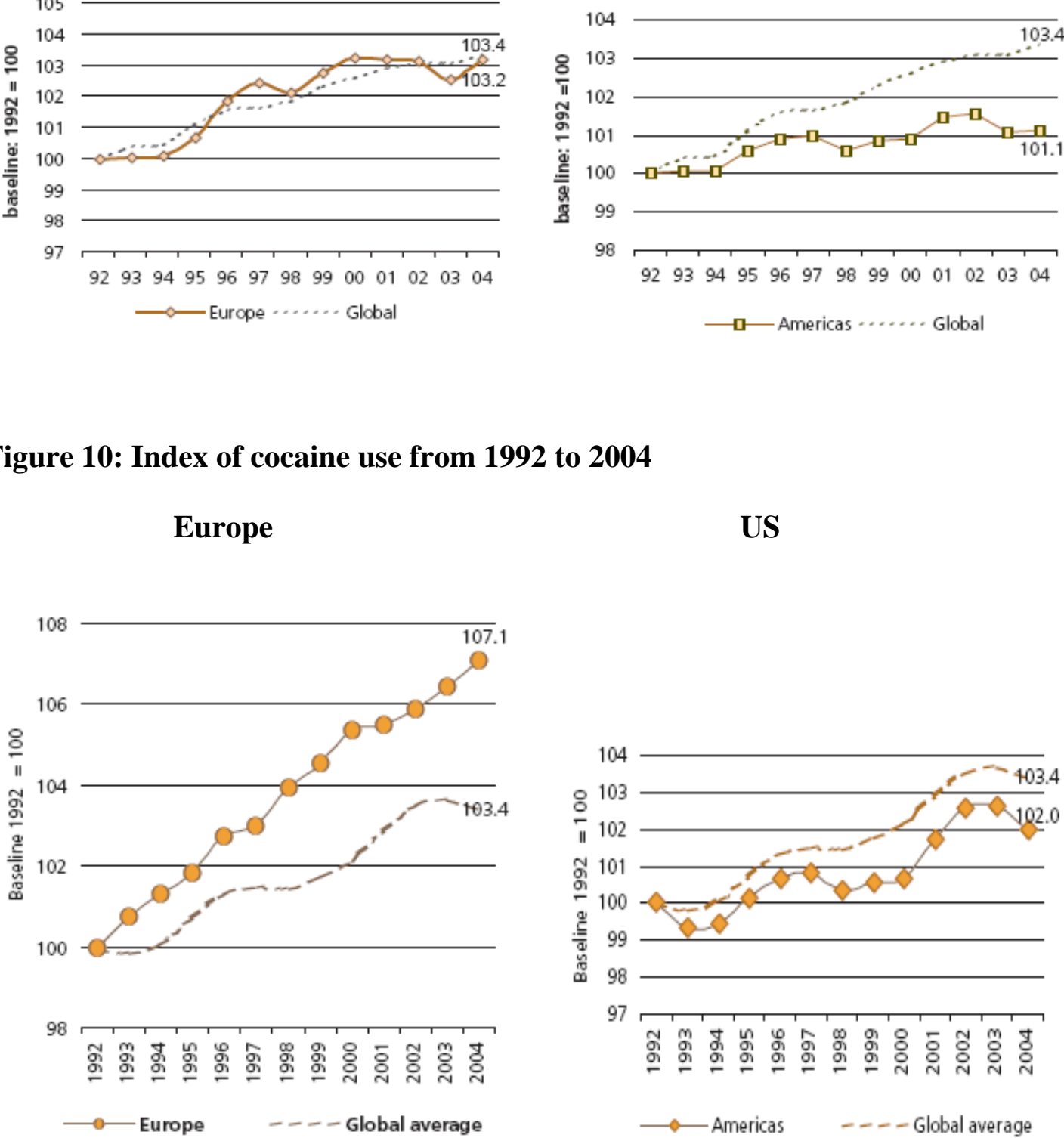
Figure 11: Index of Cannabis use
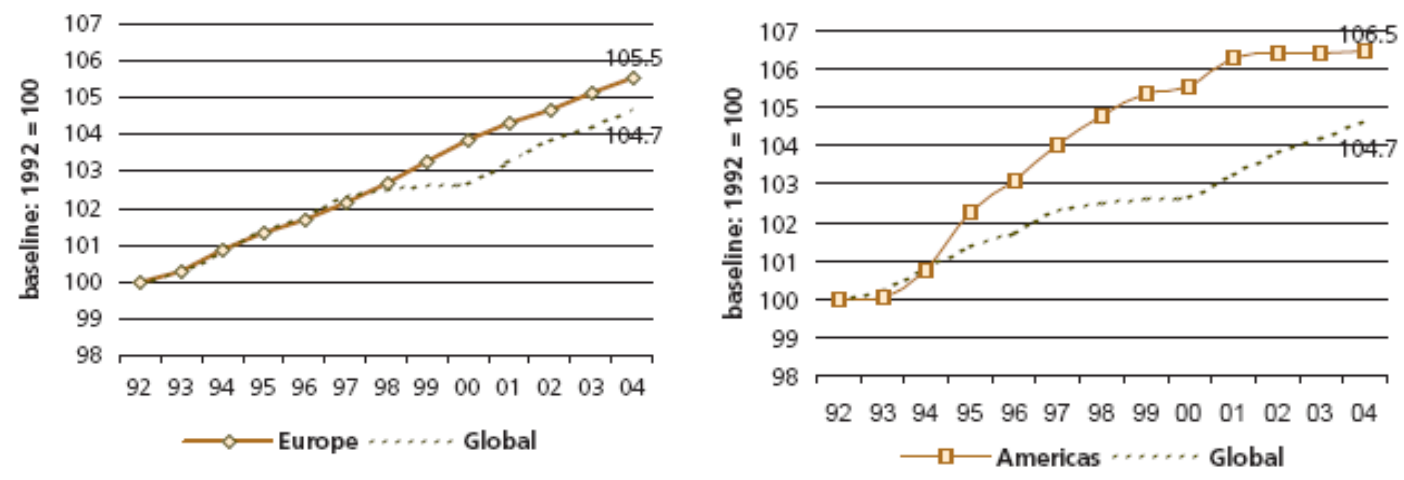

Source: United Nations, World Drug Report 2006, Office on Drugs and Crime, New York

\subsection{The collapse of the intermediation margins}

The spectacular decline in the retail prices of cocaine and heroin can only be explained by what happened with the intermediation margins in these markets. We show the evidence about these intermediation margins in figures 12 and 13 . We first concentrate on the margin between the retail and the wholesale price. The latter is not the producer price but the price paid by the dealers in the consuming markets. We will analyze the margin between the wholesale price and the producer price subsequently.

Figure 12 shows the intermediation margin between the retail and wholesale prices for cocaine and heroin. The decline of these margins is spectacular amounting to $50 \%$ or more from 1990 to 2004.

We obtain a similar result with the intermediation margins between the wholesale and the producer prices. We show the evidence in figure 13 . When computing these margins we assumed that the producer prices remained constant at their 2004 levels. We do this because we only have fragmentary information of these producer prices (see previous section). We know that these prices tended to increase though. Thus we tend to underestimate the decline of the margin. We observe from figure 13 that the margin between the wholesale and producer price declined even more than the margin between retail and wholesale price, dropping by 60 to $80 \%$. 


\section{Figure 12}
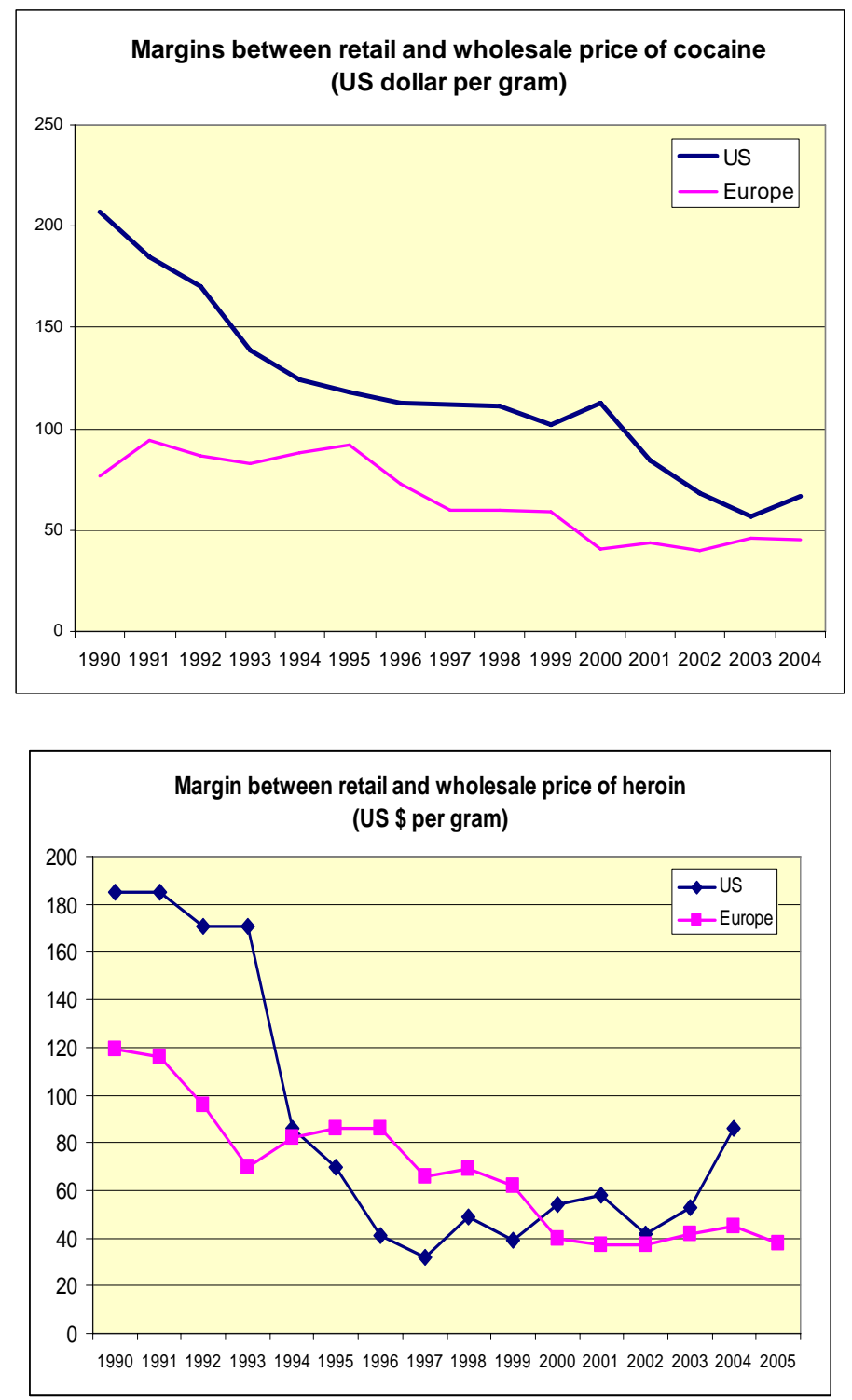

Source: United Nations, World Drug Report 2006, Office on Drugs and Crime, New York

From the previous evidence it can be concluded that the spectacular decline in the retail prices of cocaine and heroin can be explained almost exclusively by the spectacular declines in the intermediation margins between producers, wholesalers and retailers. Thus the story that can be told about the observed decline in retail prices is the following. For some reason (to be analyzed in the next section) the intermediation margins in the cocaine and heroin markets dropped spectacularly since at least 1990. This had the effect of reducing retail prices substantially. The latter then stimulated the demand for drugs by end-users. This increased demand in turn had the effect of pushing up producer prices for coca leafs and opium. As the producer prices 
make up only a tiny fraction of the retail value of drugs (even after the decline in the retail prices) the second round effect of the increased producer prices in the retail markets were extremely small.

Figure 13:
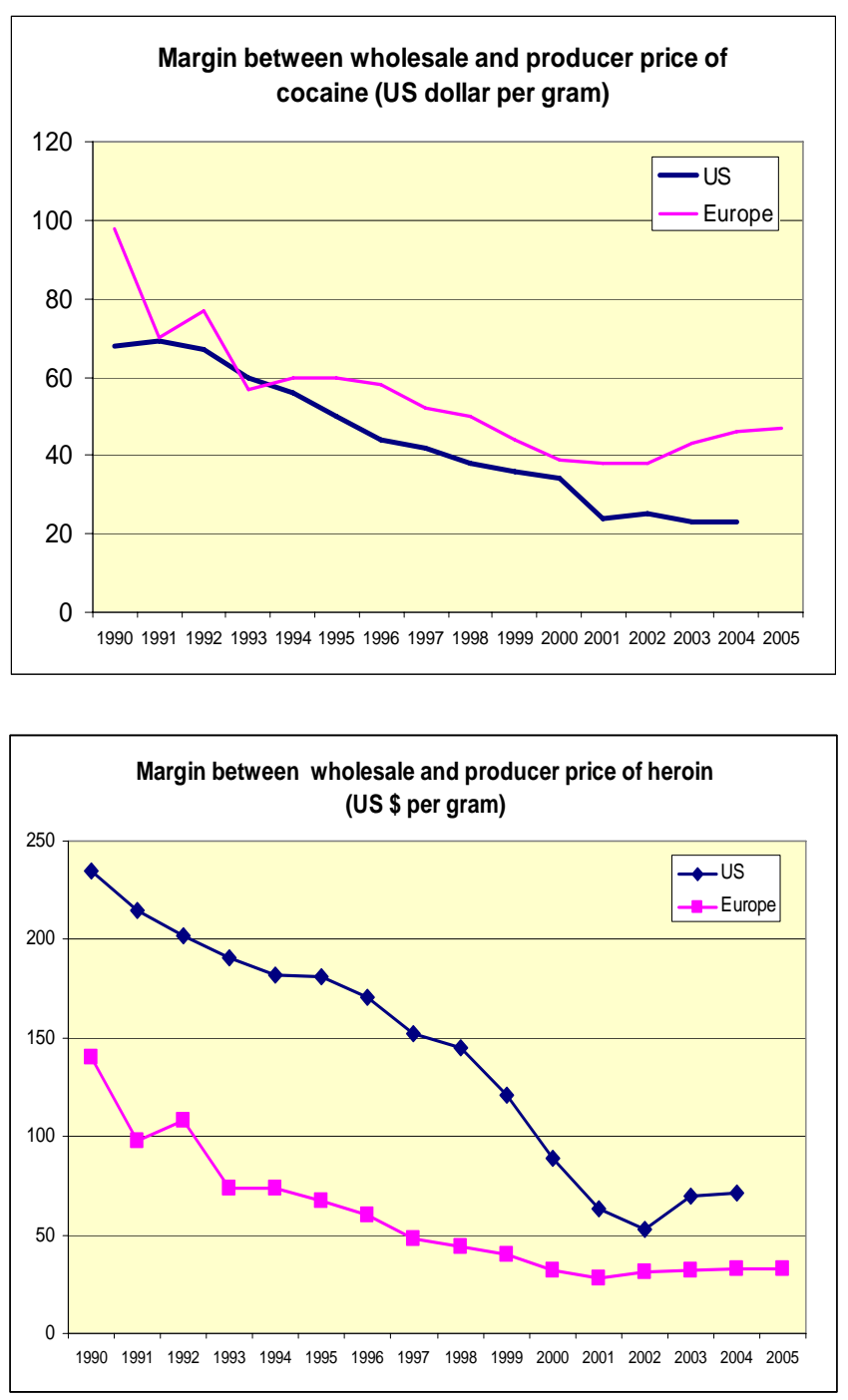

Source: United Nations, World Drug Report 2006, Office on Drugs and Crime, New York

We now come to the question of why the intermediation margins declined so much, which leads us to the analysis of the effects of globalization on the drug market. 


\section{Globalization and the intermediation margins in the drug markets}

Our hypothesis is that globalization has worked in two ways to reduce the intermediation margins in the drug business. The first one is the efficiency effect of globalization $^{9}$. Transport costs have been reduced and the use of the new IT has allowed to dramatically improve the efficiency of the distribution of drugs and made it possible to cut on the number of intermediaries. This new IT has also made the communication between demand and supply safer and quicker, leading to better stock management, and has much improved communication among dealers. In addition, the explosion in the size of international trade flows has made it possible to better conceal the transport and the distribution of drugs. Finally, the sophistication of the international financial markets has greatly increased the scope for money laundering to remain undetected. All this has led to a decline in the cost of distributing drugs.

The second mechanism through which globalization has lowered the intermediation margin is through the risk premium effect. Globalization has opened the borders of many countries with a surplus of poor and low skilled workers. Richard Freeman of Harvard has estimated that the opening up of China, India, Russia since the 1980s has doubled the world supply of cheap and unskilled workers (Freeman(2005)). As a result, millions of "have-nots" who have little to loose, may have been attracted by the fantastic intermediation margins provided by the drug market. This massive entry into the business of transporting and distributing drugs by people who are willing to take risks may help to explain the decline in the risk premium. This inflow of new intermediaries has had the additional effect of increasing competition in the drug distribution.

It is not easy to find direct evidence for this hypothesis. There is, however, some indirect evidence available that tends to support the risk premium effect. This is the number of drug seizures observed since 1990. We show the evidence in figure 14 . We observe that there is a dramatic increase in the worldwide seizures of heroin and cocaine. Since 1980 the number of worldwide seizures has increased by a factor of 10 . (A similar phenomenon is observed with other drugs). Such an increase in seizures can be interpreted in two ways. First, it can be used as evidence that the effectiveness of law enforcement has increased. Second, it can be the result of increased trafficking.

\footnotetext{
${ }^{9}$ See States (1996) and especially Naím(2005) for detailed descriptions of how globalization had changed the drug business.
} 
If the first hypothesis is the correct one, we should observe an increase in the intermediation margin. The reason is that more forceful law enforcement increases the risk of distributing drugs. The strongly declining margins observed in the previous section, however, cast doubts on this interpretation. We may then conclude that the large increases in drug seizures have also been influenced by increased trafficking. This lends support to our hypothesis that globalization has led to an increased supply of individuals willing to enter the drug distribution business. It also follows that the large increases in drug seizures have been insufficient to curb the surge in trafficking.

\section{Figure 14: Global drug seizures}

\section{Opium (in heroin equivalents)}
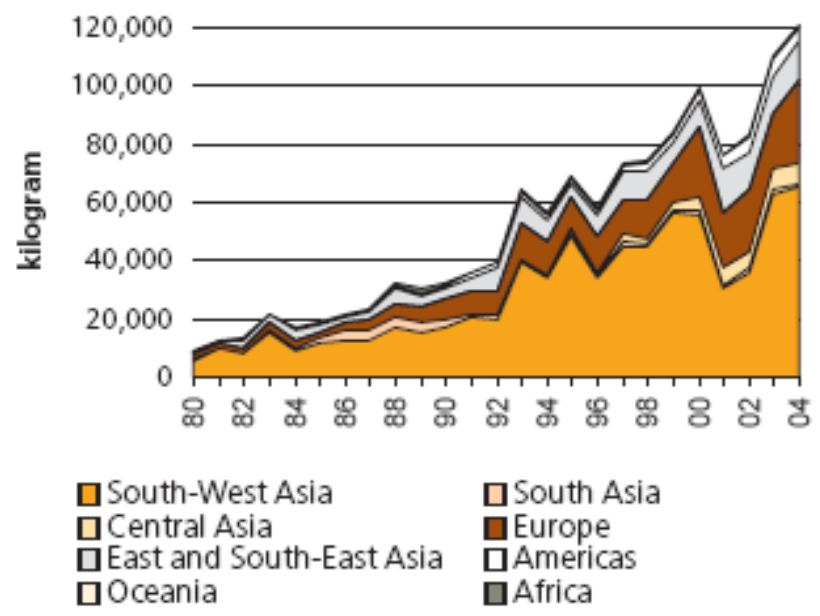

\section{Cocaine}

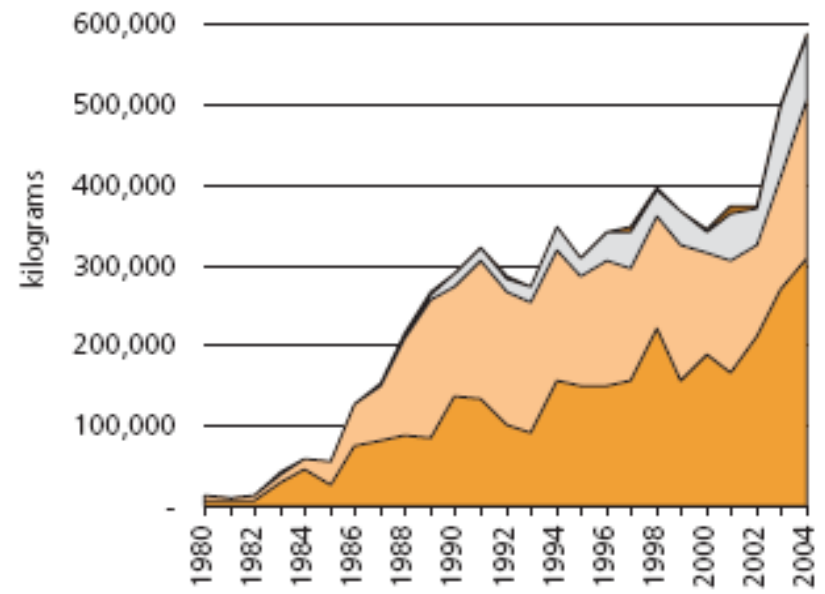

$\square$ South America $\square$ North America $\square$ Europe $\mathbf{Q}$ Other

Source: United Nations, World Drug Report 2006, Office on Drugs and Crime, New York 


\section{Globalization and inflation}

The effect of globalization on the retail prices of drugs is not an isolated phenomenon. There is a large academic literature analyzing the impact of globalization on the rate of change of consumer prices (inflation) in general even in situations where there are some very strong pressures to increase inflation as during the last oil crises. There is a broad consensus that globalization has tended to put downward pressure on the consumer price indices of the industrial countries. One of the mechanisms is the following. Globalization has increased the intensity of competition. The new industries emerging in Asia compete ferociously with older industries in the developed countries. This tends to lower import prices and to reduce profit margins in the import competing industries of the developed countries. As a result the aggregate price levels in these countries tend to decline ${ }^{10}$.

Thus the way globalization affects the general price level in developed countries is similar to the mechanisms that operate in the drug markets. The difference is one of size of the effects. It is clear that the effect of globalization on the aggregate price indices has been much smaller than the effects on the retail prices of drugs. The IMF (2005) for example, estimates that globalization may have reduced inflation by $1 \%$ per year. When one accumulates this over a 15-year period this would amount to a decline of the consumer price levels of approximately 20\%. This is sizable but still significantly lower than the 50 to $80 \%$ decline in the retail price of drugs during the last 15 years. It should be noted, however, that in individual markets, e.g. textile, computers, price declines of similar magnitude as in the drug markets have been recorded.

\section{Policy implications}

We showed that the forces of globalization have led to large declines in the retail prices of drugs (cocaine and heroin). This together with the evidence about the price elasticity of the demand for drugs suggests that globalization has contributed towards increasing drug use. Thus globalization has conflicted with the stated objectives of

\footnotetext{
${ }^{10}$ There are other mechanisms leading to a downward pressure on the consumer prices. In particular, the integration of the low wage workers of China, India and other Asian countries has exerted a downward pressure on wage levels in the developed countries. This has tended to reduce the rate of growth of consumer prices. .For an analysis of these effects see Rogoff(2004), BIS(2006), IMF World Economic Outlook(2006), Borio and Filardo(2006), Kohn(2006).
} 
governments in the world. Almost everywhere these governments aim at reducing drug use.

These governments have followed different approaches towards achieving the objective of a lower drug use. A first approach consists in containing supply by law enforcement measures (control and interdiction of production and distribution). A second approach consists in undertaking measures that reduce demand for drugs (prevention, information and education).

Most governments use a combination of these two types of policies. Some put more emphasis on supply policies while others focus more on demand policies ${ }^{11}$. The results of our paper allow us to draw a tentative conclusion on the relative effectiveness of these two approaches in the context of a globalized environment. This is that globalization has tended to make demand policies relatively more effective than supply policies. We show this in the context of the model of demand and supply of drugs in figure 15. We assume that globalization continues to induce a decline in the intermediation margin. Graphically, the retail supply curve continues to shift downwards. As a result, demand is stimulated further. These forces of globalization tend to undermine the effectiveness of supply containment policies. The reason can be seen as follows. Supply containment policies tend to raise the margin between retail and producer prices. In the absence of globalization this would raise the retail supply curve upwards. Globalization, however, greatly reduces this upward movement, and on balance continues to push it downwards. The main reason follows from a paradox contained in supply policies: as the latter raise the intermediation margin, they increase the profitability of the drug business and thus they tend to attract many new agents seeking to capture the enlarged profit opportunities (see Becker et al(2004)) ${ }^{12}$.

The reduced effectiveness of supply policies in a world of globalization creates the scope for an enhanced use of demand policies. Even if the latter are not more effective than before, their relative effectiveness may have increased. We show the effects of demand policies in figure 15 by a downward movement of the demand curve. We also note that the high elasticity of the retail supply curve has the effect of making this

\footnotetext{
${ }^{11}$ There are other differences between governments in the use they make of harm reduction. Some governments give harm reduction a central place in their overall drug policies; other governments give it only scant importance. The role of harm reduction in drug policies is outside the scope of this paper.

${ }^{12}$ Becker et al. (2004) show that if the demand of illicit drugs is relatively inelastic, interdiction and law enforcement will actually increase the resources devoted to the supply of drugs.
} 
shift in the demand curve relatively effective in reducing demand because it has only a very small impact on the price of drugs ${ }^{13}$. These policies can be used to counteract the effects of globalization on the supply curve.

This conclusion, it should be stressed, can only be tentative. More research effort should go toward analyzing the conditions in which demand policies can be made to work. In addition, our conclusion does not imply that supply containment policies should be abandoned. These are likely to remain an important part of any drug policy aiming at reducing drug use.

\section{Figure 15: Effects of demand policies}

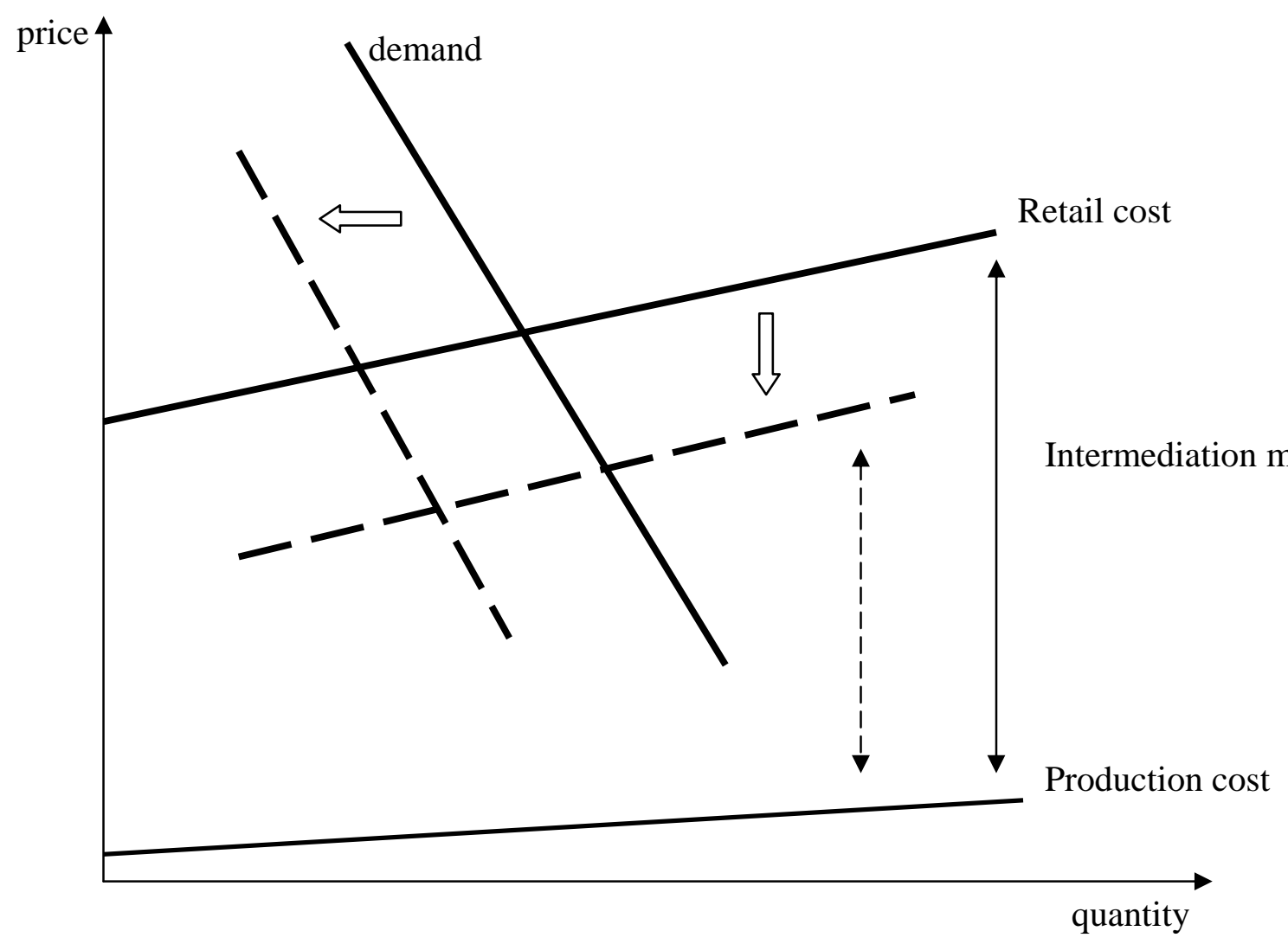

\footnotetext{
${ }^{13}$ This relative effectiveness of demand policies exists today because the margin between retail and producer prices is still very high. If globalization further reduces this margin, this effect would be reduced. We are still very far removed from this possibility, however.
} 


\section{Conclusion}

The retail prices of major drugs like cocaine and heroin have declined dramatically during the last two decades. This price decline has tended to offset the effects of drug policies aimed at reducing drug use in major industrial countries.

The main finding of this paper is that the decline in the retail prices of drugs is related to the strong decline in the intermediation margin (the difference between the retail and producer prices) in the drug business. This margin has tended to decline by more than 50\% since 1990 in the US and in Europe.

We developed the hypothesis, and gave some evidence, that globalization has been an important factor behind the decline of the intermediation margin. Globalization has achieved this effect in two ways. We called the first one the efficiency effect of globalization. Lower transport costs, the use of the new IT and the enhanced worldwide competition have allowed to dramatically improve the efficiency of the distribution of drugs. In addition, the greater efficiency of the distribution process had the effect of making it easier to conceal the transport and the stock management of drugs.

The second mechanism through which globalization has lowered the intermediation margin is through the risk premium effect. Globalization has opened the borders of many countries with a surplus of poor and low skilled workers. Millions of "havenots" who have little to loose, may have been attracted by the fantastic intermediation margins provided by the drug market. This massive entry into the business of transporting and distributing drugs by people who are willing to take risks helps to explain the decline in the risk premium.

We concluded with some thoughts about the effects of globalization on the effectiveness of drug policies and argued that globalization may have increased the relative effectiveness of policies aiming at reducing the demand of drugs. 


\section{References}

Abt Associates, (2000), Illicit Drugs: Price Elasticity of Demand and Supply, Report Prepared for the National Institute of Justice, Cambridge,

Bank for International Settlements, Annual Report 2005-2006.

Becker, G., Murphy, K., and Grossman, M., (2004), The Economic Theory of Illegal Goods: The Case of Drugs, NBER Working Paper, no. 10976, December.

Borio, C., and Filardo, A., (2006), Globalization and Inflation: New Cross-Country Evidence on the Global Determination of Domestic Inflation, mimeo, Bank for International Settlements.

Caulkins, J.P. (1996), Estimating elasticities of demand for cocaine and heroin with DUF data. Pittsburgh: Working Paper, Heinz School of Public Policy, Carnegie Mellon University.

Caulkins, J.P., Reuter, P., Iguchi, M., and Chiesa, J., (2005), How Goes the "War on Drugs”?. An Assessment of U.S. Drug Problems and Policy, Drug Policy Research Center, Rand, Occasional Paper.

Caulkins, J. Reuter, P., Taylor, L., (2006), Can Supply Restrictions Lower Price? Violence, Drug Dealing and Positional Advantage, Contributions to Economic Analysis \& Policy.

Dave, D., (2004), The Effects of Cocaine and Heroin Prices on Drug-Related Emergency Department Visits, NBER Working Paper, no. 10619, July.

Freeman, F., (2005), What Really Ails Europe (and America): The Doubling of the Global Workforce, the Globalist Paper, June.

Grossman, Michael (2004). "Individual Behaviors and Substance Abuse: The Role of Price,” NBER Working Paper No. 10948.

International Monetary Fund, (2005), World Economic Outlook, Washington DC, September.

Kohn, D., (2006), The Effect of Globalization on Inflation and their Implications for Monetary Policy, Remarks at the Federal Reserve Bank of Boston $51^{\text {st }}$ Economic Conference, Chatham, Massachusetts, June 16.

Kuziemko, I., and Levitt, S., (2003), An Empirical Analysis of Imprisoning Drug Offenders, unpublished manuscript.

Naím, M., (2005, Illicit. How Smugglers, Traffickers, and Copycats are Hijacking the Global Economy, Doubleday, New York. 
Reuter, P., (2001), The Limits of Supply-side Drug Control, The Milken Institute Review, First Quarter, pp. 14-23.

Rogoff, K., (2004), Globalization and Global Disinflation, in Federal Reserve Bank of Kansas City, Monetary Policy and Uncertainty, Papers and Proceedings of 2003 Jackson Hole Symposium.

Saffer, H., and Chaloupka, F., (1995), The Demand for Illicit Drugs, NBER Working Paper, no. 5238, August.

States, P., (1996), Global Habit: The Drug Problem in a Borderless World, Washington, D.C., Brookings Institution.

United Nations, World Drug Report 2006, Office on Drugs and Crime, New York

Ramful, P., and Zhao, X., (2003), Demand for Marijuana, Cocaine and Heroin: A Multivariate Probit Approach, Department of Econometrics and Business Statistics, Monash University, Australia. 


\section{Appendix: Evolution of retail prices of drugs in the US, 1981-2003}

The figures in this appendix all come from: Office of National Drug Control Policy http://www.whitehousedrugpolicy.gov/publications/price_purity/

Figure 1: Annual Predicted Price of One Expected Pure Gram of Powder Cocaine

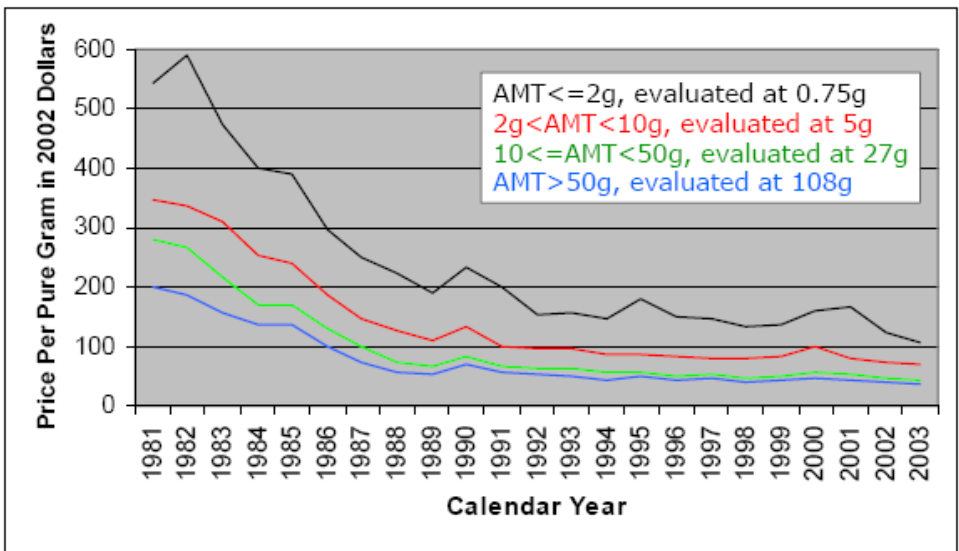

Figure 17. Annual Price of One Expected Pure Gram of Heroin

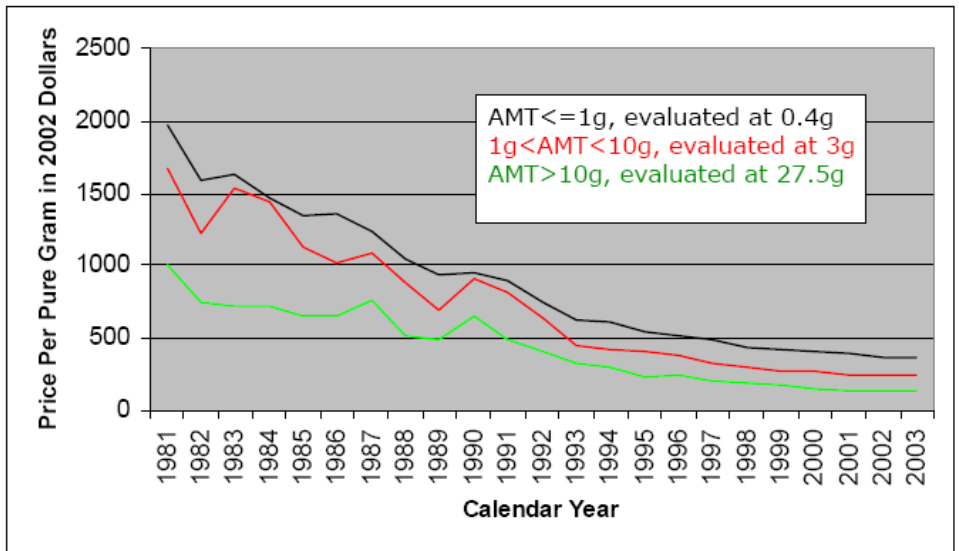


Figure 24. Annual Price of One Expected Pure Gram of d-Methamphetamine

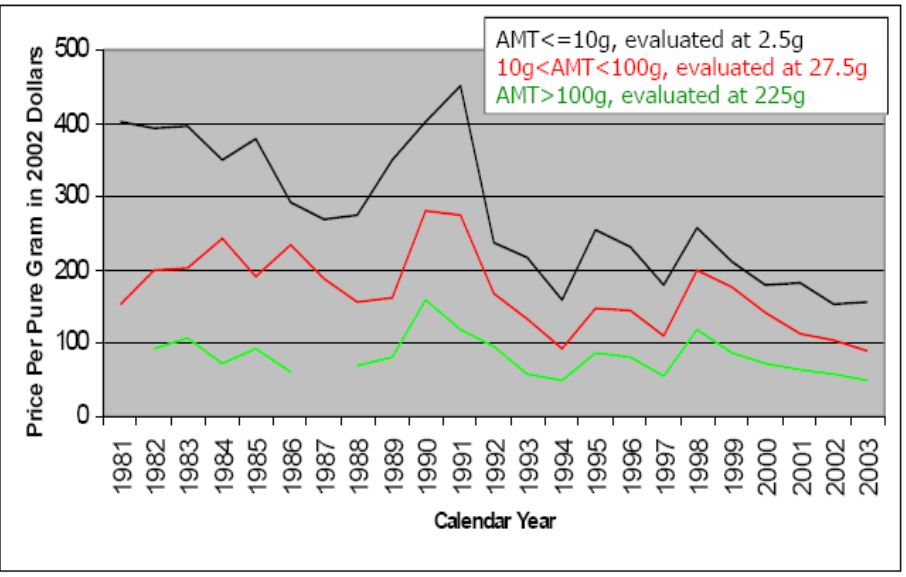

Source: http://www.whitehousedrugpolicy.gov/publications/price_purity/

Figure 8: City Trends in the Retail Price of One Expected Pure Gram of Powder Cocaine

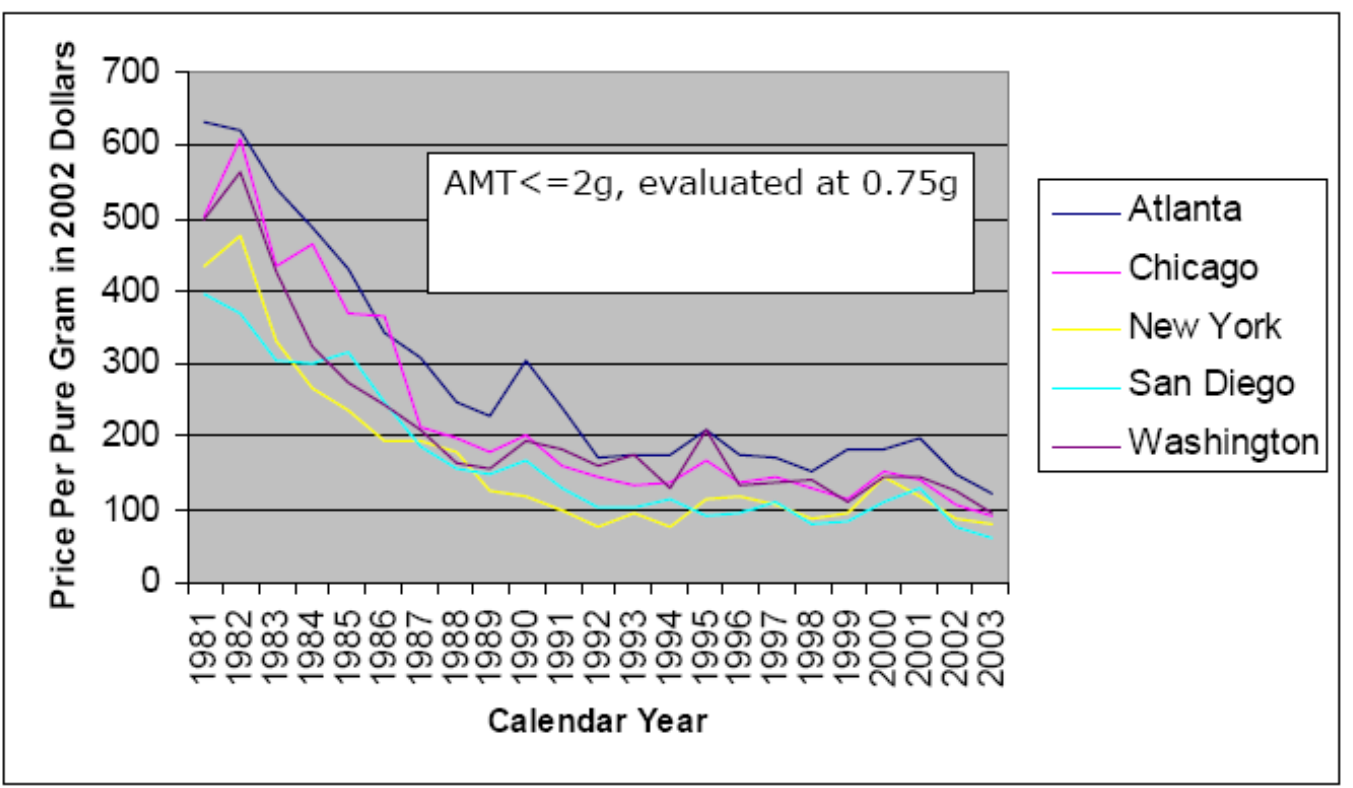




\section{CESifo Working Paper Series}

(for full list see www.cesifo-group.de)

1924 Adrian Pagan and M. Hashem Pesaran, On Econometric Analysis of Structural Systems with Permanent and Transitory Shocks and Exogenous Variables, February 2007

1925 Hans-Werner Sinn, The Welfare State and the Forces of Globalization, February 2007

1926 Michael Smart, Raising Taxes through Equalization, February 2007

1927 Øystein Foros, Kåre P. Hagen and Hans Jarle Kind, Price-Dependent Profit Sharing as an Escape from the Bertrand Paradox, February 2007

1928 Balázs Égert, Kirsten Lommatzsch and Amina Lahrèche-Révil, Real Exchange Rates in Small Open OECD and Transition Economies: Comparing Apples with Oranges?, February 2007

1929 Aleksander Berentsen and Cyril Monnet, Monetary Policy in a Channel System, February 2007

1930 Wolfgang Ochel, The Free Movement of Inactive Citizens in the EU - A Challenge for the European Welfare State?, February 2007

1931 James K. Hammitt and Nicolas Treich, Statistical vs. Identified Lives in Benefit-Cost Analysis, February 2007

1932 Wilhelm Kohler, The Bazaar Effect, Unbundling of Comparative Advantage, and Migration, February 2007

1933 Karsten Staehr, Fiscal Policies and Business Cycles in an Enlarged Euro Area, February 2007

1934 Michele Bernasconi and Paola Profeta, Redistribution or Education? The Political Economy of the Social Race, March 2007

1935 Axel Dreher, Martin Gassebner and Lars-H. R. Siemers, Does Terror Threaten Human Rights? Evidence from Panel Data, March 2007

1936 Naércio Aquino Menezes Filho and Marc-Andreas Muendler, Labor Reallocation in Response to Trade Reform, March 2007

1937 Gebhard Flaig and Timo Wollmershaeuser, Does the Euro-zone Diverge? A Stress Indicator for Analyzing Trends and Cycles in Real GDP and Inflation, March 2007

1938 Michael Funke and Michael Paetz, Environmental Policy Under Model Uncertainty: A Robust Optimal Control Approach, March 2007 
1939 Byeongchan Seong, Sung K. Ahn and Peter A. Zadrozny, Cointegration Analysis with Mixed-Frequency Data, March 2007

1940 Monika Bütler and Michel André Maréchal, Framing Effects in Political Decision Making: Evidence from a Natural Voting Experiment, March 2007

1941 Giacomo Corneo and Olivier Jeanne, A Theory of Tolerance, March 2007

1942 Qing Hong and Michael Smart, In Praise of Tax Havens: International Tax Planning and Foreign Direct Investment, March 2007

1943 Yin-Wong Cheung, Dickson Tam and Matthew S. Yiu, Does the Chinese Interest Rate Follow the US Interest Rate?, March 2007

1944 Panu Poutvaara and Mikael Priks, Unemployment and Gang Crime: Could Prosperity Backfire?, March 2007

1945 Burkhard Heer, On the Modeling of the Income Distribution Business Cycle Dynamics, March 2007

1946 Christoph A. Schaltegger and Lars P. Feld, Are Fiscal Adjustments less Successful in Decentralized Governments?, March 2007

1947 Giovanni Facchini, Marcelo Olarreaga, Peri Silva and Gerald Willmann, Substitutability and Protectionism: Latin America's Trade Policy and Imports from China and India, March 2007

1948 C. Mirjam van Praag and Bernard M. S. van Praag, The Benefits of Being Economics Professor A (and not Z), March 2007

1949 Astrid Hopfensitz and Frans van Winden, Dynamic Choice, Independence and Emotions, March 2007

1950 Guglielmo Maria Caporale and Luis A. Gil-Alana, A Multivariate Long-Memory Model with Structural Breaks, March 2007

1951 Mattias Ganslandt and Keith E. Maskus, Wholesale Price Discrimination and Parallel Imports, March 2007

1952 Michela Redoano, Fiscal Interactions Among European Countries. Does the EU Matter?, March 2007

1953 Stefan C. Wolter, Rémy Hübschi and Matthias Müller, Push or Pull? An Empirical Analysis of the Demand for Individual Project Grants from the Swiss National Science Foundation, March 2007

1954 Scott Alan Carson, African-American and White Inequality in the American South: Evidence from the $19^{\text {th }}$ Century Missouri State Prison, March 2007 
1955 Peter Egger, Marko Koethenbuerger and Michael Smart, Do Fiscal Transfers Alleviate Business Tax Competition? Evidence from Germany, March 2007

1956 Panu Poutvaara and Lars-H. R. Siemers, Smoking and Social Interaction, March 2007

1957 Stephan Danninger and Fred Joutz, What Explains Germany's Rebounding Export Market Share?, March 2007

1958 Stefan Krasa and Mattias Polborn, Majority-efficiency and Competition-efficiency in a Binary Policy Model, March 2007

1959 Thiess Buettner and Georg Wamser, Intercompany Loans and Profit Shifting Evidence from Company-Level Data, March 2007

1960 Per Pettersson-Lidbom and Mikael Priks, Behavior under Social Pressure: Empty Italian Stadiums and Referee Bias, April 2007

1961 Balázs Égert and Carol S. Leonard, Dutch Disease Scare in Kazakhstan: Is it real?, April 2007

1962 Paul De Grauwe and Pablo Rovira Kaltwasser, Modeling Optimism and Pessimism in the Foreign Exchange Market, April 2007

1963 Volker Grossmann and Thomas M. Steger, Anti-Competitive Conduct, In-House R\&D, and Growth, April 2007

1964 Steven Brakman and Charles van Marrewijk, It’s a Big World After All, April 2007

1965 Mauro Ghinamo, Paolo M. Panteghini and Federico Revelli, FDI Determination and Corporate Tax Competition in a Volatile World, April 2007

1966 Inés Macho-Stadler and David Pérez-Castrillo, Optimal Monitoring to Implement Clean Technologies when Pollution is Random, April 2007

1967 Thomas Eichner and Ruediger Pethig, Efficient $\mathrm{CO}_{2}$ Emissions Control with National Emissions Taxes and International Emissions Trading, April 2007

1968 Michela Redoano, Does Centralization Affect the Number and Size of Lobbies?, April 2007

1969 Christian Gollier, Intergenerational Risk-Sharing and Risk-Taking of a Pension Fund, April 2007

1970 Swapan K. Bhattacharya and Biswa N. Bhattacharyay, Gains and Losses of India-China Trade Cooperation - a Gravity Model Impact Analysis, April 2007

1971 Gerhard Illing, Financial Stability and Monetary Policy - A Framework, April 2007

1972 Rainald Borck and Matthias Wrede, Commuting Subsidies with two Transport Modes, April 2007 
1973 Frederick van der Ploeg, Prudent Budgetary Policy: Political Economy of Precautionary Taxation, April 2007

1974 Ben J. Heijdra and Ward E. Romp, Retirement, Pensions, and Ageing, April 2007

1975 Scott Alan Carson, Health during Industrialization: Evidence from the $19^{\text {th }}$ Century Pennsylvania State Prison System, April 2007

1976 Andreas Haufler and Ian Wooton, Competition for Firms in an Oligopolistic Industry: Do Firms or Countries Have to Pay?, April 2007

1977 Eckhard Janeba, Exports, Unemployment and the Welfare State, April 2007

1978 Gernot Doppelhofer and Melvyn Weeks, Jointness of Growth Determinants, April 2007

1979 Edith Sand and Assaf Razin, The Role of Immigration in Sustaining the Social Security System: A Political Economy Approach, April 2007

1980 Marco Pagano and Giovanni Immordino, Optimal Regulation of Auditing, May 2007

1981 Ludger Woessmann, Fundamental Determinants of School Efficiency and Equity: German States as a Microcosm for OECD Countries, May 2007

1982 Bas Jacobs, Real Options and Human Capital Investment, May 2007

1983 Steinar Holden and Fredrik Wulfsberg, Are Real Wages Rigid Downwards?, May 2007

1984 Cheng Hsiao, M. Hashem Pesaran and Andreas Pick, Diagnostic Tests of Cross Section Independence for Nonlinear Panel Data Models, May 2007

1985 Luis Otávio Façanha and Marcelo Resende, Hierarchical Structure in Brazilian Industrial Firms: An Econometric Study, May 2007

1986 Ondřej Schneider, The EU Budget Dispute - A Blessing in Disguise?, May2007

1987 Sascha O. Becker and Ludger Woessmann, Was Weber Wrong? A Human Capital Theory of Protestant Economic History, May 2007

1988 Erkki Koskela and Rune Stenbacka, Equilibrium Unemployment with Outsourcing and Wage Solidarity under Labour Market Imperfections, May 2007

1989 Guglielmo Maria Caporale, Juncal Cunado and Luis A. Gil-Alana, Deterministic versus Stochastic Seasonal Fractional Integration and Structural Breaks, May 2007

1990 Cláudia Costa Storti and Paul De Grauwe, Globalization and the Price Decline of Illicit Drugs, May 2007 